TEXT Vol 15 No 2 (October 2011)

\title{
Prose and poetry contents
}

- Michelle Cahill, Letter to Derrida page 2

- Luke Johnson, The supermarket play page 4

- Wendell Mayo, Sententiae for fiction workshop page 11

- $\quad$ Stuart Barnes, Two poems page 13

- Dominique Hecq, Theory page 16

- Jeff Klooger, Two poems page 18

- BN Oakman, Secret heart page 20 


\section{TEXT prose}

\section{Michelle Cahill}

\section{Letter to Derrida}

Dearest,

I have been meaning to write to you for months with such intensity that now at last I am ready to begin, for your words repay no casual browsing. There is no beloved face or voice, which I hold in memory, that so affects me. I admit it is your borrowings, misquoted perhaps, postponed, but savoured nonetheless. Why, I have asked myself, for months, (no, years), does this trouble me?

You once told me there are traces of us in everything. I read our language in the streets where I walk or in the houses I enter to sleep and to breath, or in the bones of the child that I hold, or the man who has loved me with the coldness of a lover, in whom all images are reversed.

For I do concede the violence of my words. My therapist doubts if I am narcissistic. He does not even think me passive-aggressive, but you have made me know my repressions; indeed, my every fetish.

My dearest, this body of writing is a fantasy. Its words are like cells which divide and expand into an anatomy of passages. Do not trust them. They are nurtured by the lies of ink, the false promises of white space. They are shaped by perversity, their rigours are syntax. Some form into patterns, appearing not as fully present; little embryos of stories. Other words miscarry. They read like crypts of coral or broken shells, semantically fated, and asking to be filled with a different mouth.

But speak now, dearest. Deny this body of writing is yours. She is spectral, a dopplegänger, a kind of fragmentary haunting. And yet she is here, where I have always been in this blank darkness. For reading and writing - are they not like the first purlieu we come to inhabit?-a space before time, before day or night, a space of aloneness and comfort in which the one who sustains us is invisible?

Close your eyes.

Forget the rough ride. We've turned round and round in circles. With you or without, I am in a double-bind. Between the extremes of excitation and error, (terror?), between deciphering and detour do I find myself banished. How can I say what must be spoken without contradiction? Without waging war on us? I have thrown away my gods for things more tactile. Am I not this body of writing, who bears your mark, the many plurals therein, assuming but a singular completeness? How well this serves me. 
You have shown me a vividness despite your absence. For it is a wonder to play at scribbling the texts of our bodies, the bodies of our texts, outside of which, as you rightly say, il n'y a rien.

Because of you I see with your eyes, knowing that my desire to see is a desire to escape from seeing, a desire to come by delay, to hold what is empty, to taste sublimely what is impure. None of which brings me to my point.

Should I confess what is undisclosed, promise me you would deconstruct this shameless rubbish. Show me your devotion. Despise me. For accordingly, this author, this narrator, this third person, is other than me entirely. She is a whole, made up of parts. She is a ghost-ship, a phantom crew navigating the uncharted.

Pardon her composite epistles. She is like pillars of coral, each containing a thousand tiny cavities; half-coloured, half-faded, washed ashore from a reef, or swept along by a windy swell. Each piece carries its hint of another life, its clues borne out by fish and reef plankton.

On small indeterminate 'traces', as you would call them, do all my worlds rely. My nuances are fragile, playful, subtle, obstinate, and because of you, impossible. Like vibrations, you touch them and your boundaries slip away. In preserving them I am guessing. Because of you I am living with the speculative. Because of you I am swept in the currents of a partially imagined past through the appearances of what is present, to a space which I depend on for recovery.

So fatigued am I, so defeated. And yet it is to this alchemy of language I unwittingly turn, placing my entire fate in your hands.

Without you I am powerless.

Michelle Cahill's fiction has appeared recently in Southerly, Transnational Literature, Famous Reporter and Prosopisia. In 2009 she received an Australia Council grant to write fiction at Sanskriti Kendra. She has published two collections of poetry, most recently Vishvarūpa with 5IP. Michelle is co-editor of Mascara Literary Review: www.mascarareview.com

\title{
TEXT
}

\author{
Vol 15 No 2 October 2011 \\ http://www.textjournal.com.au \\ Editors: Nigel Krauth \& Kevin Brophy \\ Text@griffith.edu.au
}




\section{TEXT prose}

\section{Luke Johnson}

\section{The supermarket play}

Ken was an oldish guy. Maybe he wasn't as old as he looked. The sun had made him look very old. He'd spent a good deal of his life working outdoors, painting houses and lacquering fence panels and earning money at the race track, and the sun had accompanied him throughout these years with a severe loyalty. It'd given him blotches on the backs of his hands and down his forearms and neck, and his face was mottled with atolls which looked light and tropical beneath the stark fluorescent bulbs of the supermarket aisles. It was in quasi-retirement that Ken had taken the job at the supermarket. He said there wasn't enough money in trackwork alone, and he'd been unable to climb a ladder for some time on account of his damned head spells. Ken didn't think there was anything remarkable about the way he said damned all the time, but I liked it very much and thought it made for a pleasant and decent character trait.

'Ken, I'm going to put you in one of my plays,' I said to him one night, while the two of us were standing together stacking tins of beetroot on the shelf.

'I don't want to be in no damned play,' Ken said back to me. It was a very Ken thing to say.

'But you're the lead role,' I tried reasoning. Ken said nothing (also very Ken). I went on. 'See, it's about this guy who paints houses his whole life and gets damned head spells from having been in the sun so damned much. He says damned a damned lot of the time and carries a pocketknife on his belt which looks like something a soldier might carry for slicing up rations of spam.'

Ken took his pocketknife out of its pouch and looked closely at its blade. He was the only nightfiller to carry a pocketknife like this. The rest of us used the disposable knives issued by management. They were galvanised threepiece jobs, with flimsy razor cartridges for blades. We carried them in our shirt pockets, and if we leaned forward too steeply they fell out and broke apart on the floor and couldn't be put back together again without being bent out of shape in the process. Ken's looked old and indestructible.

'And who else is in this damned play then?' He stuck the knife end into the top of the box and cut it from ear to ear. Inside a can gurgled.

'No one else. It's strictly a one-person play. You're the lead role and the supporting ensemble, Ken. And it's quite political in parts.'

It would need to be quite political to do Ken any real justice. Damned play and damned disrespectful, ain't it? Come into this damned country. Ken was himself quite a political man. 
Shaking his head then: 'I thought plays were meant to be hell full of romantic guys called Romeo and Shakespeare and the rest of it? Never heard of no damned political play about a guy called Ken working his arse off in the sun all his life. What's he do when he gets bored?'

'Okay. Well, he congratulates himself on having lived a good and honourable life. When he gets bored of that too he masturbates. Sometimes in public. Though this is quite a rarity. Nevertheless, Ken. Okay?'

Ken shuffled awkwardly and hitched his pants. The masturbation thing worried him. I could see that it worried him. The name worried him also. Perhaps he was right to be worried about the name. I was a little worried myself. Ken may have qualified for a good and decent prose name, but who was to say it would make for a good and decent play name? The two were very different animals. You could get away with a lot more when you were writing prose. Especially when it came to names. A good prose name was like an illustration. It had only to look nice and perform the occasional action, whether it be dancing between paragraphs, or stumbling drunk from margin to margin, and that would be enough to carry its reader throughout. Lolita was an exceptional example of what could be achieved with the right combination of phonemes and some professional typesetting. Lo-lee-ta: two ripened, plump legs parted beneath the bum cheeks and a rickety motel nightstand. (Or, at the other end of the spectrum: Humbert-Humbert: out of breath but persisting on with its awkward back-and-forth rhythm.) A good and decent play name, however, had nothing to do with action or syntax or the great Franco-American dream, a good play name was one which performed with dignity across all vocal registers. Stella, for instance. You couldn't take anything away from Stella. Shouted, whispered, deep-South or thick-Polack: Stella traversed them all with clarity and decorum. And if there was one trick to writing failsafe play names that I was aware of, it was to seek out the longest possible title which couldn't be broken into any shorter derivative of itself. Stella, good. Rosencrantz, better. Mephistopheles, bravo.

Ken piped up again then. 'Hell of a goddamned play that shows a guy talking to himself and playing with himself all day long. In front of everyone too, no doubt. Mothers and grandmothers and the lot. Goddamned no kind of play I've ever heard of. That what politics is come to, goddamnit?'

God was the mother of Ken's fucker, the cunt of his faced, the jolly of his good. A lower-case god in any event. And a god he inflected with spite and without recourse to the religious tattoo on his left forearm. (I say religious, it was a Ned-Kelly-in-the-image-of-Saint-George, and more related to Ken's sense of nationalism than piety, I'm sure.)

'If it makes you feel better,' I said, 'the masturbating thing is purely nostalgic. And mostly futile. It reminds him of his younger days. He's been to war, see. Watching other people die has made him very self-congratulatory. Have you read a great deal of Mailer, Ken?' Ken shook his head without shaking it. Ken could agree and disagree like this without moving a single muscle. It was the way he breathed, the source of his breath. A belligerent breath came all the way from his gut. 'Mailer's middle name was Kingsley.' Ken didn't respond, though he breathed easier and from the larynx. 'How do you feel about Kingsley, Ken? It's almost impossible to give Kingsley an undignified slant. Wouldn't you agree? The critics will read into it. Critics love names. Makes them feel politicised to talk about names in a creative and historical context. Kingsley — at the risk of King or Kingsy, that is.' 
'Well, first of all, I ain't never been to no damned war and that ain't something you damned-well lie about neither,' Ken stated emphatically. 'And second-'

I'll stop you there, Ken. Always difficult for me to believe any old person who says they haven't ever been to war. Yes, but where did all those scars come from then? And why do you insist on saying things like, 'Come into this damned country...' and 'Damned disrespectful...'? Am I expected to believe you accumulated all those prejudices while swatting flies with paintbrushes and spoilt racing guides, while listening to silly girls laugh and drink champagne and say things like, 'Ooh, you missed a spot!' and, 'Oh, what a funny name this one has!' and, 'What's a gelding, now, darling?' Surely you must have passed at least one semester of your youth being drilled over the precision of your bootlace knots and the gradient of your morning hard-on? With a surname like Marsh too, for Christ's sake. What better name for shouting and bearing down upon than Marsh? It struck me then that maybe the play needed a second character after all. A drill sergeant. Someone to shout Marsh! whenever the audience looked tired or ready to leave.Certainly something very comical about the military and their drill sergeants.

'War is a liberty like any other,' I began explaining to Ken, who was looking puzzled and upset by this stage. At his feet a pool of blood had begun spreading slowly and outwards across the linoleum floor, the pierced beetroot heart in the box's chest pumping with supermarket fever and fear of its impending vacuous death. 'Very similar to sex in fact. Sex being the biggest of them all. Are you sure you haven't read any Mailer? How about Miller? Miller often uses liberties to make things seem truer. Although, I must admit, it's difficult to make sex seem true on the stage no matter what liberties you take. I think your character will need to use a lot of heavy language if he's to have any success with sex. Don't look so bothered, Ken. There are other tricks that can be used. And I'll see to it that the actor in charge of playing you knows his stuff. I'm afraid, however, that the war bit is an absolute must. No questions. Maybe even an injury_-just to remind the audience. Could your character affect a limp for the sake of believability and bravery, do you think? It's very important that your character seem political and brave, and I think a limp is the best way of demonstrating both these traits. In the end, it's the details that make the thing seem true and believable.'

Ken didn't seem to understand too much of what I was talking about, with all the technical play stuff and so forth. Admittedly there were some longwinded ideas in there which would need simplifying if this thing was to work in front of an audience. A prose writer might get away with such sloppiness, such contrivances, though a playwright would be found out quick-smart. It was all to do with the collective mind of the audience. The collective mind was sharp and impatient. The collective mind would disappear for refreshments and never come back. The collective mind had no reservations in leaving their seats empty and the actors looking beyond the stage lights for encouragement from the house cleaners.

'Leave it with me, Ken. I'll make you seem entirely believable and heroic at once,' I said.

'Goddamned no goddamned hero here, boy. Forget it.' The false modesty was entirely Ken-like. While the pool of blood at his feet smelled sweet as pineapple juice. 
A week later I'd finished a draft for the play. It was called The Supermarket. It wasn't a heroic play by definition, though there were some heroic parts in the middle when the main character took his pocketknife out and talked directly to the audience about how he'd been forced to kill a bare-chested Korean during the war. As he talked he used his knife to wipe sweat from his neck and this made him seem vulnerable and doubly heroic. The main character often addressed the audience directly and when he wasn't addressing the audience directly he was addressing the Kelly tattooed on his forearm directly. It was a post-Nolan Kelly and unlike Ken's lithe, romantic, horse-bound Kelly, this one rode shotgun in an army tank which was drawn onto his skin as squarely as the well-known head armour. The Kelly was a symbol of the character's sense of duty and religion, and when he chastised it he chastised himself.

'How do you get all this stuff about the tattoo just from listening to him talk? Is his forearm so big that people at the back of the theatre will understand and laugh along?'

I'd taken the idea for the play to a group workshop. I wanted to hear the other actors and playwrights say it wouldn't work. Which was largely the point of the workshop. It was a very successful workshop in this way.

'The tattoo is projected onto a screen,' I explained to them. I'd thought through the technical components in advance. It would be projected onto a screen the size of a beach towel. The audience would be able to see the hair follicles rising up out of the character's skin. His pores would glow with perspiration and ink, each one like a sweaty little porcelain eggcup.

'Popeye,' another of them jested. Everyone laughed accordingly and I felt pleased to be involved with such a successful bunch.

Several minor forearm jokes and some pleasant conjecturing later, it was decided that The Supermarket would be a suitable addition to the group's rehearsal schedule and, pending its ongoing appeal, the group's performance schedule later in the year. It was a small enough play that it could easily be performed between sets with the curtain closed, employing just the front open area of the stage, and this counted in its favour. Some concerns came to mind regarding the lead character's dislike for tight and confined places-a deal of which was a direct result of the months of his life spent locked inside a POW cell (being made to breathe the ammonia from his own urine was like holding his head over an opened tin of paint) - but I was eager for the play to go ahead and didn't wish to hamper its chances in any way by demanding extravagant props or greater floor space or any other unnecessary privilege that wasn't mine to begin with. The only suggestion I dared to make sprung from my belief that whoever was to play the part of Kingsley should first of all spend some nights observing the real-life Ken at work in the supermarket, to get a feel for his persona. The actors didn't like this idea one bit. 'Scorsese, take a chill pill,' they scoffed at me, while the other playwrights rolled their eyes at one another and smirked condescendingly. Nobody in that workshop group thought very much for field research and all of them were much older and more experienced than me.

After trialling the play with the group at the writers' centre I took it to the supermarket for Ken to read during his tea break. It'd been reduced to a one-act play as a result of some intense workshopping and much of what went on in the act wasn't written directly on the page but implied through discrepancies in the character's vision of himself. The workshoppers were big on this kind of drama: character-discrepancy drama, they called it. Ken read the lines without reading through them and slurped lukewarm coffee and when 
he'd finished he handed me the copy of the play and remarked that he wasn't happy with the setting.

'Don't like where it happens,' he said.

'It happens here, in the supermarket,' I said to him.

'I know,' he said back to me. 'I don't like it.'

'But it's based on you,' I reasoned. 'It's called The Supermarket.'

'It's me, all right,' Ken agreed. He seemed almost pleased with himself at recognising and confirming this fact.

'And you work in a supermarket. I even changed the character of the drill sergeant to a department manager.'

'Eddie,' Ken said.

'Eddie, yes. That's Eddie calling you a lousy sack of shit and firing you.'

'That's Eddie making me cry in front of the juice aisle?'

'Yes, Ken. Eddie Debbman. See how I changed the letters around so that I wasn't using his real name? It's a play on his real name. Eddie Debbman: Danny Beadman.'

'I don't like the robots either,' Ken said.

'The robots are not real, Ken. They're a metaphor for youth, for foreign invasion, for technological consumption of the species, for hand-to-hand jungle warfare. It's frightening. Just like Eddie firing you and giving your job over to a Japanese robot is frightening and at the same instant metaphoric for the way the supermarket treats its aged employees, for the way the government treats its war veterans. All of it's connected.' I waited for Ken to say something about his dislike of faux war veterans and Japanese robots in general, but he let this go for the time being. 'Do you see?' I implored him.

Ken looked at me. He was a man whose eyebrows gave the appearance of a frown even when he wasn't frowning. 'And I didn't go much on all the talking. There was too much talking,' he said. 'All talking, really.'

'Ken, it's a play. If it was a prose story I could do away with a large part of the talking, I could just say things outright. But in a play that's all you have, the dialogue. The dialogue and the setting. It's very difficult. You can see how difficult it is. Look at the way I have you talking to your arm. Which is a sort of a metaphor too, Ken. Do you think the audience is going to be able to see what's going on here? Imagine, I'm going to project the tattoo onto a screen the size of a beach towel and whenever you start talking I'm going to light up the screen and it'll be a metaphor for God and for the character's sense of self. It's quite a religious and political play, Ken, and quite risk-taking. I told you it would be quite political and religious. Were you wondering how I was going to broadcast the character's tattoo right across the audience, so that even the people in the back would see and be able to laugh along? Or did you think the character would need forearms the size of Popeye's?'

Ken didn't laugh at the Popeye joke. I considered that I'd been fooled by the workshopping group. Fickle, I thought. Fickle was a word I often 
pronounced in my head. Out loud I preferred the direct expletive. I imagined it was the opposite for Ken: goddamned fool out loud, daddy-cunt-faced clitclicker in his head.

'And it's all double-meanings and that?' Ken asked. 'The robots and the setting and all of it?'

At last, you've turned the page, Ken: metaphor, metonymy, mise-enabyme! Yes, this is you smack bang in the middle of the play discussing your wariness of appearing smack bang in the middle of plays, functioning yourself as a metonymy of yourself, as an infinite regression of yourself. Now you see! Clever, clever, clever. Do you not think? You, Ken: the ultimate metaphor of instruction and deliverance and futile masturbation. How about it? What do you say? Pat on the back, eh?

'It's better than I thought it would be,' Ken conceded. It was a noble and difficult thing for him to say and he said it nobly and concedingly.

'Ken, you must agree to play yourself,' I said at that moment. I'd only just decided and it seemed right.

'I ain't no damned play actor,' Ken scoffed.

'What acting? You would be playing yourself, Ken.'

'Too old. Besides, I ain't got the time to be worrying about any of that business. Got to keep me greyhounds fed and looked after.'

'But, Ken-'

I thought then to tell Ken the story of the ANZAC, something to rouse his self-belief. Not the story every Australian is familiar with, the one so often expounded through the medium of Television Miniseries (to date the most provocative means of communicating both the pragmatic horrors of war and the tenderness of masculine camaraderie at once), but rather my own personal account of the ANZAC, how eager to demonstrate my inborn and indebted respect, I'd leaned from the window of a first-floor apartment one 25 April cheering and clapping the houndstooth procession past Heiner's Hair Salon and toward the town hall clock, when one of the processors, an old chap sporting every medal known to Caucasian man save the Western movie star's shiny Sherriff badge, stopped the march dead in its tracks and pointed up at me and told me to stop acting like such a goddamned hard-on (goddamned, Ken-I swear I'm not making any of this up!)and show some goddamned reverence for the poor sons of bitches who hadn't come back, and when his pals began patting him on the back and telling him good job, Smithy, well, I may as well have been the hard-on who'd just leaned out his first-floor window to spit on the crippled widow of one of those poor sons of bitches, right in the wheelchair, the old grey-tooth!

But instead of telling the ANZAC story I said: 'Will you at least come to the play's premiere, Ken? To call "goddamned bravo" from the first row? For authenticity's sake? To show those other playwrights and actors how they got it all wrong.'

\section{$\underline{\text { Ken }}$}


$\underline{\mathrm{Me}}$

No? Okay. Okay, Kingsy.

(Curtain)

Luke Johnson's stories have been published in HEAT, Island, Going Down Swinging and Mascara Literary Review. He teaches academic writing at UNDS and cultural studies at UTS, where he is currently working towards his PhD in literary theory and creative writing. He lives in Mt Keira with his wife andson.lemajoker@hotmail.com

TEXT

Vol 15 No 2 October 2011

http://www.textjournal.com.au

Editors: Nigel Krauth \& Kevin Brophy

Text@griffith.edu.au 


\section{TEXT prose}

\section{Wendell Mayo}

\section{Sententiae for fiction workshop}

— To write good fiction, you have to use words.

— So that's his "fuck," this is someone else's "fuck." Try to not get them confused.

- I wonder if this is a condition, like I could go to the doctor and say, "I've got terminal meta-meta."

— Like, "Full-On Dragon Twist" ...You may think it's the name of an ice cream special,

but it's also a wrist lock!

— Like, I hate this kid in your story, he's a brat, why does he keep screaming?

- He's sort of like an undeveloped fetus... he's like a stem cell, yeah, he's like a stem cell;

he can be grown into a kidney.

- The damn solar system...

- The shallowness of the shallow past...

— Now that I think about it, I love my idea.

- A short story is like a thong, you have a pair of boxers here.

- But I like the banana scene.

— People bite other people when they're having sex.

- So the wife in the bedroom scene serves her purpose, I mean, in terms of the fiction, in terms of serving the fiction.

- Any of you guys in this room worn a dress? I have, but not why you think.

- From jewels to junk, there's a story in there somewhere.

— You guys like talkin' to yourselves? That's so good. I love talkin' to myself.

- Like, if anyone is going to play fast and loose with my imagination, I am going to play

fast and loose with my imagination. 
- Hey, it's my starry night, don't screw with it.

Wendell Mayo is author of three books of fiction: two story collections, Centaur of the North and B. Horror and Other Stories; and a novel-in-stories, In Lithuanian Wood. He is Professor of English at Bowling Green State University where he teaches in the Master of Fine Arts Program in Creative Writing.

\section{TEXT}

Vol 15 No 2 October 2011

http://www.textjournal.com.au

Editors: Nigel Krauth \& Kevin Brophy

Text@griffith.edu.au 


\section{TEXT poetry}

\section{Stuart Barnes}

\section{Letters}

... more than kisses, letters mingle souls

— John Donne

The paper's blinding, like a salt flat, and blank as a trepanned convalescent; the pen's a poised kris.

Do I begin with Dear?

A noncommittal Hello?

Taking a deep breath,

restraining a sneer, I write his name in red:

five little letters.

We met a year ago at an inner city club: cancerous smokes, fists in the air, Apollo-perfect men.

He could talk six feet under water. Once, with wax, I fashioned a spread of feathers, and then guided him in flight,

but he soared too close to the razored blades of the sun; oh he was green as a sapling.

But Christ could he scare the skies with his tigers eyes!

Eventually I tired of his magniloquence, the tango 'round my swelling doubts and so, a wild sirocco,

I careened from his Black Sea.

Our relationship didn't change subtly, like the passing of the moon through her phases,

but theatrically, like the shifting of tectonic plates or the plummeting of a grand red drape - and with it the sound of a thousand sirens singing.

The echoes of brass bells and sailors' cries are still ringing. Ultimately I had to cull him, a cane toad, a rabbit or a kangaroo:

he was simply too reckless with his red soldiers, so couldn't care less his 'three little letters' could possibly infect me.

And of all people, he, he, he the recovering junkie - was so quick 
to pass judgement: my drinking 'Aboriginal'.

The nine-inch nail in the coffin: he dismissed my unconditional love with a Judas kiss. I would have accepted libation or fate.

Suddenly my hand starts trembling with rage; aware I'll never write more than his Christian name I carve a bloody X through the polluted page.

[Quotation: line from 'So Young' by Suede from Suede, Nude Records, 1993]

\section{Song}

\section{for Donna Tartt}

The month to husband (but 'Je ne vais jamais me marier!' you once exclaimed), a New York restaurant: pocket Lolita (ninety pounds is all she weighs

with a height of sixty inches), you tangoed the herringbone, outdazzling the motes

in a scarf (a dash of red, the paintings of Corot), and a tailored, magician black suit.

'I'm so excited to meet you I can hardly speak!' - the Mississippi twang rolled slow and sweet. Squeezing easily beside me, you wiped your nose's tip, silvery-pink with outside's falling chill, and blinked those eyes, elliptical and feline-like, ice green as tourmaline.

I knew so very little - T.S.

Eliot on an answering machine, an infamous proclamation: 'My life is like Candide'

- and knew I'd leave that day knowing little more.

though,

Demure as you were,

about your routine tricks, you regaled me with marvellous childhood tales whilst picking at your pear and calamari, pouring another glass of Billecart: a great-grandfather spoon-feeding you blackstrap molasses, enormous doses of codeine cough syrup for tonsillitis (consequently two years were submerged in an altered state of consciousness), and supping whisky at bedtime.

Mesmerized, very much buzzed on your southern belle perfume, I hallucinated the long drugged afternoons and evenings, the languorous undersea

existence, you staring at a View-Master reel of Peter Pan flying over London, fantasizing about flying with him, and wondered: the source of inspiration? seedlings fermented in those rich and fertile liquids? ...

A decade on (the world on tenterhooks), I cradle in my palms the Biblical books - The Little Friend: steamy gothic horror, snakes and methamphetamine, a torn-off blackbird wing; The Secret History: hubris, murders, modern Greek mythology - Technicolor parrots in a sepia menagerie;

my finger's poised to page-turn volume three. 
[Quotation: line from Lolita by Vladimir Nabokov, Olympia Press, Paris, 1955; lines from 'Sleepytown: A Southern Gothic Childhood, with Codeine', by Donna Tartt, Harper's Magazine 286 (July 1992): 60-66]

Born in Hobart, living in Melbourne, Stuart Barnes is currently preoccupied with psychiatry's pitfalls, global politics, the Classics, and the body, all of which are explored in his poetry and short stories. Stuart Barnes $<$ stuart barnes sstu808@yahoo.com>

\section{TEXT}

Vol 15 No 2 October 2011

http://www.textjournal.com.au

Editors: Nigel Krauth \& Kevin Brophy

Text@griffith.edu.au 


\section{TEXT poetry}

\section{Dominique Hecq}

\section{Theory}

for Mark Carthew

To hell with Lacan and his linguisteries, says one Next time I hear Barthes I'll puke, says the other

That makes bullfighting sound appealing

I'd rather take up ballroom dancing

And so they do-after a fashion

It's rhetoric in the eye and in the ear with the expert conjugation of limbs of fabulous form playing on the I as guitar strings strum and spangled jargon turns to stunning sentences with prepositional grace and grand structure - all in perfect rhyme and the present tense they announce their favoured metaphors:

Paso Doble, Fox Trot the Samba and Rhumba

they enhance their grammar with fluid ornament. The mood

of this discourse is periphrastic and muscles up into lyrics of glamorous freight

silken transitions resonate in the air

to meter and flair and love of words

Dominique Hecq is the author of The Book of Elsa (a novel), Magic, Mythfits and Noisy Blood (fiction), The Gaze of Silence, Good Grief and Couchgrass (poetry) as well as two short plays (One Eye Too Many, and Cakes \& Pains performed in 2004). She won the Martha Richardson Medal for poetry (2006), and her poetry collection Out of Bounds was released by re.press in 2009. With Russell Grigg and Craig Smith, she co-authored Female Sexuality: The Early Psychoanalytic Controversies. She has published in the areas of literary studies, translation, creative writing and psychoanalysis. She is a Senior 
Lecturer in Writing at Swinburne University of Technology.

DHecq@groupwise.swin.edu.au

\section{TEXT}

Vol 15 No 2 October 2011

http://www.textjournal.com.au

Editors: Nigel Krauth \& Kevin Brophy

Text@griffith.edu.au 


\section{Jeff Klooger}

\section{Autobiographical poem}

The thought of an autobiographical poem still troubles and eludes me.

— Jill Jones

It's not what you cannot understand that vexes

but what you won't accept:

the plain old arbitrary and astounding fact

of definition: let $\mathrm{X}=\mathrm{Y}$, let it

stand for, take the place of - let this

mean that.

An autobiographical poem, for example, is a poem that tells the story of the poet's life (or part thereof), just as an autobiographical book tells the story of its author's life, not the story of the book's life, it's gestation in the mind of the author and the mysterious byways of language, the pangs of its birth, all the cigarettes that smouldered into oblivion, the hairs that greyed, the wrinkles self-doubt forged upon the brow, and then the blocks of texts blinking in and out of existence on screens from bayside Melbourne to Boston, the paper, stamped and sliced and stitched, the bright new volumes packed and shipped, arranged on shelves to wink down at unguarded browsers like street-corner harlots: 'Buy me, sweetheart. I'll give you a good time.'

As for stories, they're hypocrites, as are all words.

Hypocrisy is necessary to tell truths and untruths alike. The story of a life is no life - as those who try to live their lives like stories learn.

Don't try to pretend you do not know, whether it suits you or not. This is just how things are.

A poem will never tell you its story. It might caress you or slap you in your unsuspecting face, but it won't tell. It's just as well. So many lives in one, the tale would never end. 


\section{Between the lines *}

Not thinking, not needing to think, I pluck the breath from other poet's mouths, build my house on borrowed foundations.

No matter. We all perch

on the shoulders of giants, don't they say?

Being humbler, I stand on the backs

of creatures my own size, steal inspiration

from brothers and sisters without compunction.

All the words are mine, the meanings what I make them. Legally and morally I am okay. But this line-spinning is a trick, and tricks unsettle. Is it facile not to start from nothing, digging fingers into the mud of the life around and within you?

Have I nothing to say wholly my own?

But what is that?

I'm stuck so tight in this world, who can say where I end, where the world begins?

And in this mess of nonsense, how you make some fleeting, fragile sense means less than that you make it.

Thinking now, I think

I'll scruple less, write more, and damn all critics.

* A technique for starting poems by writing lines in response to the lines of other poems

Jeff Klooger has had work published in a number of Australian literary journals, including Meanjin, Overland, Westerly, Famous Reporter, Retort Magazine and dotlit. He has a PhD in social theory and philosophy from La Trobe University. jeffklooger@optusnet.com.au

\section{TEXT}

Vol 15 No 2 October 2011 


\section{TEXT poetry}

\section{BN Oakman}

\section{Secret heart}

I cannot truly claim

to be blocked: there are endings,

titles, beginnings, mostly false,

but also cul-de-sacs

and always there's ordure

seeping through every line

and break

until the whole is infected.

The muse surrenders

sometimes, and only, to patience,

so I wait, pencil sharpened,

pad at hand, Hemingway's

detector on stand-by, attending

moving pictures

of dreams, heeding

secret soundtracks of the heart.

BN Oakman's poetry has been published in literary journals, magazines and newspapers in Australia, the UK and the USA and recorded for ABC Classics on Peter Cundall Reads War Poetry. He was awarded a grant by the Literature Board of The Australia Council for 2009 and a chapbook, Chalk Dust: Poems from the Social Domain (Mark Time Books), appeared the same year. A fulllength collection of his poems, In Defence of Hawaiian Shirts, was published by Interactive Press in 2010. He lives in Central Victoria and has taught economics at universities in Australia and in England. www.bnoakman.com

\section{TEXT}

Vol 15 No 2 October 2011 